\title{
Investigation of the Anti-inflammatory, Hypoglycemic Activity and Median Lethal Dose (LD50) Level of Limonene in Mice and Rats
}

\author{
Betül Sever Yılmaz' ${ }^{1}$ Hanefi Özbek²* \\ ${ }^{1}$ Ankara University, School of Pharmacy, Department of Pharmacognosy, Ankara, Turkey \\ ${ }^{2}$ Istanbul Medipol University, School of Medicine, Department of Medical Pharmacology, Istanbul, Turkey
}

\section{ABSTRACT}

The aim of this study is to investigate the anti-inflammatory, hypoglycemic activity and median lethal lose $\left(\mathrm{LD}_{50}\right)$ level of limonene mice and rats.

Lethal dose levels were investigated using the probit analysis method. For the measurement of anti-inflammatory activity, seven separate work groups were established and limonene was administered in three different doses $0.15,0.30,0.60 \mathrm{~mL} /$ $\mathrm{kg}$. Indomethacin and etodolac were used as reference anti-inflammatory agents.

For the evaluation of hypoglycemic activity, 6 separate work groups, consisting of healthy and diabetic mice were established and glibenclamide was used as the reference agent.

The $\mathrm{LD}_{50}$ level of limonene was determined to be $2.77 \mathrm{~mL} / \mathrm{kg}$. It is determined that all administered dosages of limonene possess anti-inflammatory activity; among these, $0.30 \mathrm{~mL} / \mathrm{kg}$ was equivalent to indomethacin, and the remaining dosages were equivalent to etodolac. No hypoglycemic activity of limonene was observed in healthy and diabetic mice.

As a consequence, it is concluded that limonene did not show hypoglycemic activity, but possessed a strong anti-inflammatory activity.

Keywords: Limonene, anti-inflammatory activity, hypoglycemic activity, median lethal dose, rats, mice.

\section{INTRODUCTION}

Foeniculum vulgare Miller, (fennel) (Umbelliferae) is an annual, biennial or perennial aromatic herb, depending on the variety, and has been known since antiquity in Europe and Asia Minor. The leaves, stalks and seeds (fruits) of the plant are edible ${ }^{1}$. Extracts of the Foeniculum vulgare Miller (fennel) seeds are used in traditional Turkish medicine as an anti-inflammatory agent ${ }^{2}$. The anti-inflammtory, hypoglycemic and hepatoprotective effects of fennel were

*Corresponding author: Hanefi Özbek, e-mail: hozbek@medipol.edu.tr (Received 16 November 2017, accepted 01 December 2017) 
demonstrated by our previous scientific studies ${ }^{3-7}$. The volatile components of subsequent fennel seed extracts determined by chromatographic analysis contain trans-anethole, fenchone, methylchavicol, limonene, $\alpha$-pinene, camphene, $\beta$-pinene, $\beta$-myrcene, $\alpha$-phellandrene, 3 -carene, camphor, and cisanethole ${ }^{8}$. The major components of essential oil samples are $\alpha$-pinene, limonene, fenchone, methychavicol and trans-anethole ${ }^{6}$.

Several studies related to limonene exist. Del-Toro Arreola et. al. reported that D-limonene modulates the immune response in BALB/c mice with lymphoma ${ }^{9}$. This study reported that limonene attenuates the gastric carcinogenesis enhanced by sodium chloride via increased apoptosis and decreased ODC activity in gastric cancers ${ }^{10}$.

In our previous research we demonstrated that the volatile oil of fennel extract produced anti-inflammatory activity (0.050 and $0.200 \mathrm{~mL} / \mathrm{kg}$ doses); additionally, volatile fennel oil showed hypoglycemic activity 4 hours after its application $^{3}$. However, fixed fennel oil did not produce hypoglycemic activity ${ }^{4-7}$. In order to determine the compound responsible for these activities, we initiated a series of studies. In the present study we aimed to investigate the anti-inflammatory and hypoglycemic activities of limonene, one of the major compounds of volatile fennel oil extract and determined its lethal dose levels.

\section{METHODOLOGY}

\section{Animals}

Sprague-Dawley rats and Mus musculus Swiss albino mice were maintained in the animal laboratory. The animals were housed in standard cages with food and water ad libitum, at room temperature $\left(22 \pm 2^{\circ} \mathrm{C}\right)$ with artificial light from 7.00 a.m. to 7.00 p.m., and provided with pelleted food. The ambient temperature was $22 \pm 2{ }^{\circ} \mathrm{C}$, ambient $\mathrm{RH}$ was $\% 55-60$ and the rats were housed in groups. The approval of the Animal Ethics Committee was obtained.

\section{Chemicals}

(R)-(+)-Limonene was obtained from Aldrich (Steinheim-Germany), Lambdacarrageenan Type IV, indomethacin and alloxan were obtained from Sigma (Steinheim, Germany), etodolac was obtained from FAKO (İstanbul, Turkey) and Glibenclamide was obtained from Nobel, İstanbul, Turkey. Indomethacin and Etodolac were solved with ethyl alcohol.

\section{Acute Toxicity}

Swiss albino mice were randomly assigned to nine groups, with six animals in each group. The first group was treated with isotonic saline solution (ISS) (0.9\% 
$\mathrm{NaCl}$ ) and employeded as a control group. The other eight groups were treated with limonene given intraperitoneally (ip) in increasing dosages of $0.20,0.32$, $0.40,0.80,1.60,3.20,4.80$ and $6.40 \mathrm{~mL} / \mathrm{kg}$ body weight. The mortality in each cage was assessed $72 \mathrm{~h}$ after administration of limonene. The percentage mortalities were converted to probits. Regression lines were fitted by the method of least squares and confidence limits for the $\mathrm{LD}_{1}, \mathrm{LD}_{10}, \mathrm{LD}_{50}, \mathrm{LD}_{90}$ and $\mathrm{LD}_{99}$ values, and were calculated by the method of Litchfield \& Wilcoxon and Kouadio et al. ${ }^{11-12}$.

\section{Anti-inflammatory Activity}

The method of Winter et. al. with slight modification was employed ${ }^{13}$. Forty-two rats were divided into seven groups of six animals each. The rats were starved for $12 \mathrm{~h}$ and deprived of water only during the experiment. Deprivation of water was to ensure uniform hydration and to minimize variability in oedematous response. Inflammation of the right hind paw was induced by injecting $0.05 \mathrm{~mL}$ fresh lambda carrageenan (phlogistic agent) into the subplantar surface. Control Group I was given ISS and Control Group II was given ethyl alcohol. The third group (Reference Group I) received indomethacin (3 mg/kg, ip) and the fourth group (Reference Group II) received etodolac (50 mg/kg, ip) while the remaining three groups received the extract at doses of $0.15 \mathrm{~mL} / \mathrm{kg}, 0.30 \mathrm{~mL} / \mathrm{kg}$ and $0.60 \mathrm{~mL} / \mathrm{kg} \mathrm{ip}^{14-15}$. The doses utilized in the current study have been chosen according to the $\mathrm{LD}_{1}$ value $\left(\mathrm{LD}_{1}=1.01147 \mathrm{~mL} / \mathrm{kg}\right)$.

The measurement of foot volume was accomplished by a displacement technique using the plethysmometer (Ugo Basile 7140 plethysmometer, Italy), immediately before and three hours after the injection. The inhibition percentage of the inflammatory reaction was determined for each animal by comparison with controls and calculated by the following formula ${ }^{12}$ :

I \% $=[(1-(\mathrm{dt} / \mathrm{dc})] \times 100$

where $d t$ is the difference in paw volume in the drug-treated group and $d c$ the difference in paw volume in the control group.

\section{Preparation of Alloxan Diabetic Mice}

Mice were starved for $18 \mathrm{~h}$. and diabetes was induced by an ip injection of 150 $\mathrm{mg} / \mathrm{kg}$ of alloxan monohydrate in ISS. This procedure were repeated three times $^{16}$. 7 days after the last treatment, mice with blood glucose levels of 200 $\mathrm{mL} / \mathrm{dL}$ and higher were taken into the study ${ }^{17}$.

\section{Hypoglycemic Activity in Diabetic Mice}

Animals were randomly divided into three groups of six animals each. Group I 
mice received $0.1 \mathrm{~mL}$ ISS ip. The animals of Group II were used as a standard, and treated orally with glibenclamide at a dose of $3.0 \mathrm{mg} / \mathrm{kg}$. Group III received ip with $0.15 \mathrm{~mL} / \mathrm{kg}$ body weight of limonene. Blood glucose levels were determined before treatment, 1, 2, 4 and $24 \mathrm{~h}$ after treatment by applying glucose oxidase peroxidase (Abbott, United Kingdom).

\section{Hypoglycemic Activity in Normal (Healthy) Mice}

The same protocol described above for normal mice was applied in mice made diabetic by administering $150 \mathrm{mg} / \mathrm{kg}$ i.p. of alloxan monohydrate. Also in this case, three groups of six animals each were used.

\section{Statistical Analysis}

Results were reported as mean \pm standard error of mean (SEM). The total variation was analyzed by performing a one-way analysis of variance (ANOVA). An LSD (least significant difference) test test) was used for determining significance. Probability levels of less than 0.05 were considered significant ${ }^{18}$. Lethal dose levels were investigated by the probit analysis method. The medium effective dose $\left(\mathrm{ED}_{50}\right)$ value was calculated by non-linear regression analysis (SigmaPlot 2004 for Windows Version 9.01).

\section{RESULTS AND DISCUSSION}

\section{Acute Toxicity}

The results of lethal doses are shown in Table 1. The intraperitoneal medium lethal dose $\left(\mathrm{LD}_{50}\right)$ value for the total number of animals was found to be $2.77796 \mathrm{~mL} / \mathrm{kg}$.

Table 1. Lethal doses of limonene.

\begin{tabular}{c|c|c|c}
\hline \multirow{2}{*}{$\begin{array}{c}\text { Dose } \\
\text { Lethal doses }\end{array}$} & $\begin{array}{c}\text { Dor } \\
\text { (mL/kg) }\end{array}$ & $\begin{array}{c}\text { Lower } \\
(\mathbf{m L} / \mathbf{k g})\end{array}$ & $\begin{array}{c}\text { Upper } \\
(\mathrm{mL} / \mathbf{k g})\end{array}$ \\
\cline { 3 - 4 } & 1.01147 & 0.16705 & 1.67328 \\
$\mathrm{LD}_{1}$ & 1.59225 & 0.49302 & 2.29631 \\
$\mathrm{LD}_{10}$ & 2.77796 & 1.68481 & 3.73663 \\
$\mathrm{LD}_{50}$ & 4.84663 & 3.61616 & 9.68089 \\
$\mathrm{LD}_{90}$ & 6.77774 & 4.74994 & 20.72301 \\
$\mathrm{LD}_{99}$ & & & \\
\hline
\end{tabular}

\section{Anti-inflammatory Activity}

Table 2 illustrates the antioedema effect of intraperitoneally administered limonene on carrageenan paw oedema in rats. Limonene showed significant antiinflammatory effects in all doses studied, peaking at a dose of $0.30 \mathrm{~mL} / \mathrm{kg}(76.29$ 
\% inhibition), and with a lesser degree of inhibition at a dose of $0.15 \mathrm{~mL} / \mathrm{kg}$ (51.729\%) and a dose of $0.60 \mathrm{~mL} / \mathrm{kg}(51.732 \%)$.

Table 2. Anti-inflammatory effect of limonene.

\begin{tabular}{lccc}
\hline Groups & Dose & Paw edema $(\% \mathrm{~mL})$ & Inhibition (\%) \\
\hline Control-I (ISS) & $0.1 \mathrm{~mL}$ & $1.043 \pm 0.127$ & - \\
Control-II (ethyl alcohol) & $0.1 \mathrm{~mL}$ & $0.988 \pm 0.112$ & - \\
Indomethacin & $3 \mathrm{mg} / \mathrm{kg}$ & ab $0.024 \pm 0.061$ & 87.44 \\
Etodolac & $50 \mathrm{mg} / \mathrm{kg}$ & abc $0.559 \pm 0.040$ & 43.42 \\
Limonene & $0.15 \mathrm{~mL} / \mathrm{kg}$ & abc $0.504 \pm 0.075$ & 51.72 \\
Limonene & $0.30 \mathrm{~mL} / \mathrm{kg}$ & abde $0.247 \pm 0.074$ & 76.29 \\
Limonene & $0.60 \mathrm{~mL} / \mathrm{kg}$ & abcf $0.503 \pm 0.106$ & 51.73 \\
\hline F value & & 18.196 & \\
\hline$p$ value & & 0.000 \\
\hline
\end{tabular}

Data presented as mean \pm standard error of mean $(n=6)$.

Post-hoc LSD test:

$\mathrm{a}: p<0.05$ compared to control-I (ISS) group,

$\mathrm{b}: p<0.05$ compared to control-II (ethyl alchohol) group,

$\mathrm{c}: p<0.05$ compared to indomethacin group,

$\mathrm{d}: p<0.05$ compared to etodolac group,

e : $p<0.05$ compared to limonene $0.15 \mathrm{~mL} / \mathrm{kg}$ group,

$\mathrm{f}: p<0.05$ compared to limonene $0.30 \mathrm{~mL} / \mathrm{kg}$ group.

Compared to the controls, the greatest anti-inflammatory activity was observed in the first reference group receiving indomethacin with a $87.44 \%$ regression of inflammation. Etodolac, the second reference agent, showed significant but weaker anti-inflammatory activity with a $43.42 \%$ regression of oedema.

Limonene has a significantly lower anti-inflammatory effect compared to indomethacin at $0.15 \mathrm{~mL} / \mathrm{kg}$ and $0.60 \mathrm{~mL} / \mathrm{kg}$ doses, and a comparable effect at a 0.30 $\mathrm{mL} / \mathrm{kg}$ dose. When compared to etodolac, the limonene had a statistically similar effect at $0.15 \mathrm{~mL} / \mathrm{kg}$ and $0.60 \mathrm{~mL} / \mathrm{kg}$, and displayed higher activity at $0.30 \mathrm{~mL} / \mathrm{kg}$. Limonene had significantly lower anti-inflammatory activity at $0.15 \mathrm{~mL} / \mathrm{kg}$ and $0.60 \mathrm{~mL} / \mathrm{kg}$ compared to $0.30 \mathrm{~mL} / \mathrm{kg}$, whereas the dose of $0.15 \mathrm{~mL} / \mathrm{kg}$ showed no statistically meaningful difference with a $0.60 \mathrm{~mL} / \mathrm{kg}$ dose.

The medium effective dose $\left(\mathrm{ED}_{50}\right)$ value of limonene was found to be $0.142 \mathrm{~mL} / \mathrm{kg}$. 


\section{Hypoglycemic Activity}

The blood glucose levels of the alloxan diabetic mice are given in Table 3 and Figure 1. Table 4 and Figure 2 demonstrate theblood glucose levels of normal mice. Limonene did not have any hypoglycemic effect in alloxane-induced diabetic mice.

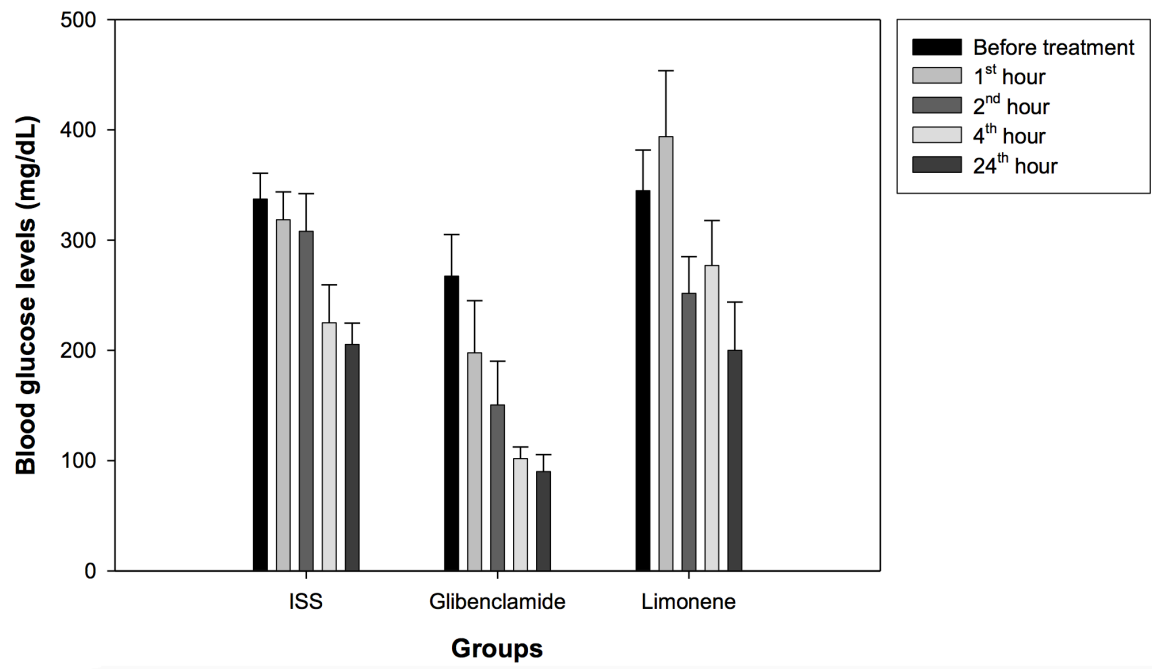

Figure 1. Blood glucose levels in glibenclamide, limonene and control groups of mice with alloxane-induced diabetes.

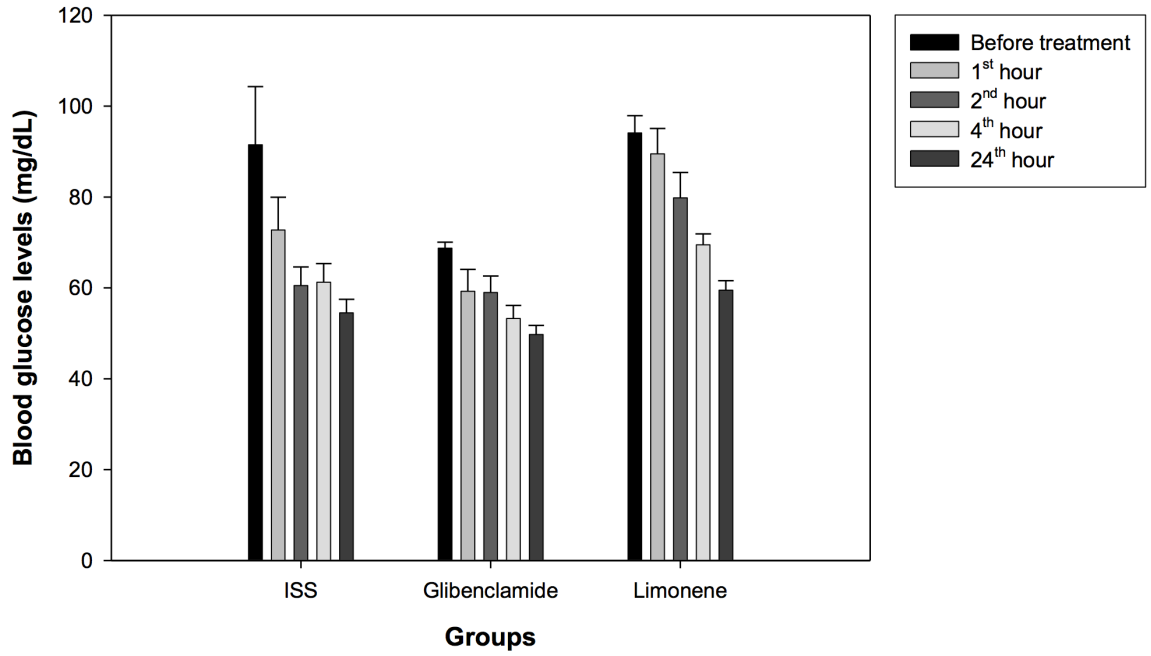

Figure 2. Blood glucose levels in glibenclamide, limonene and control groups of healthy mice. 
Table 3. Blood glucose levels in glibenclamide, limonene and control groups of mice with alloxane-induced diabetes.

\begin{tabular}{lccccc}
\hline \multirow{2}{*}{ Groups } & \multicolumn{5}{c}{ Fasting blood glucose $(\mathbf{m g} / \mathbf{d L})$} \\
\cline { 2 - 6 } & Before treatment & $\mathbf{1}^{\text {st }}$ hour & $\mathbf{2}^{\text {nd }}$ hour & $\mathbf{4}^{\text {th }}$ hour & 24 $^{\text {th }}$ hour \\
\hline Control (ISS) & $337.2 \pm 23.4$ & $318.4 \pm 25.3$ & $308.0 \pm 34.2$ & $225.0 \pm 34.4$ & $205.4 \pm 19.3$ \\
\hline Glibenclamide & $267.3 \pm 37.7$ & $197.8 \pm 47.3$ & ${ }^{\mathrm{a}} 150.5 \pm 39.7$ & ${ }^{\mathrm{a}} 101.8 \pm 10.6$ & ${ }^{\mathrm{a}} \mathbf{9 0 . 1} \pm 15.4$ \\
\hline Limonene & $344.8 \pm 36.8$ & ${ }^{\mathrm{b}} 393.8 \pm 59.9$ & $251.7 \pm 33.3$ & ${ }^{\mathrm{b}} 277.0 \pm 40.7$ & ${ }^{\mathrm{b}} 200.0 \pm 43.8$ \\
\hline$F$ values & 1.509 & 4.053 & 4.559 & 7.901 & 4.753 \\
\hline$P$ values & 0.253 & 0.039 & 0.028 & 0.005 & 0.027 \\
\hline
\end{tabular}

Data were represented as mean \pm standart error of mean.

Post-hoc LSD test:

a: $\mathrm{p}<0.05$ compared to ISS group.

b: $\mathrm{p}<0.05$ compared to glibenclamide group.

Table 4. Blood glucose levels in glibenclamide, limonene and control groups of healthy mice.

\begin{tabular}{lccccc}
\hline \multirow{2}{*}{ Groups } & \multicolumn{5}{c}{ Fasting blood glucose $(\mathrm{mg} / \mathrm{dL})$} \\
\cline { 2 - 6 } & Before treatment & 1 $^{\text {st }}$ hour & 2 $^{\text {nd }}$ hour & 4 $^{\text {th }}$ hour & 24 $^{\text {th }}$ hour \\
\hline Control (ISS) & $91.50 \pm 12.8$ & $72.75 \pm 7.2$ & $60.50 \pm 4.1$ & $61.25 \pm 4.1$ & $54.50 \pm 3.0$ \\
\hline Glibenclamide & $68.75 \pm 01.3$ & $59.25 \pm 4.8$ & $59.00 \pm 3.6$ & $53.25 \pm 2.9$ & $49.75 \pm 2.0$ \\
\hline Limonene & $94.1 \pm 03.8$ & ${ }^{\mathrm{b}} 89.5 \pm 5.6$ & ${ }^{a b} 79.8 \pm 5.6$ & ${ }^{\mathrm{b}} 69.5 \pm 2.4$ & ${ }^{\mathrm{b}} 59.5 \pm 2.1$ \\
\hline F values & 3.840 & 6.709 & 5.729 & 7.316 & 4.257 \\
\hline$P$ values & 0.054 & 0.012 & 0.020 & 0.010 & 0.043 \\
\hline
\end{tabular}

Data were represented as mean \pm standart error of mean.

Post-hoc LSD test:

a: $\mathrm{p}<0.05$ compared to ISS group.

b: $\mathrm{p}<0.05$ compared to glibenclamide group.

It is observed that limonene group had significant levels of glucose in blood among healthy mice during the $1^{\text {st }}, 2^{\text {nd }}, 4^{\text {th }}$ and $24^{\text {th }}$ hours compared to glibenclamide group, but the ISS group had significant levels only during the $2^{\text {nd }}$ hour.

In our previous research with volatile fennel oil, we demonstrated fennel's antiinflammatory and hypoglycemic activities. In this part of the study - one of the studies of a series that we have initiated to determine the compound or compounds responsible - limonene, a major compound of the contents of volatile 
fennel oil, anti-inflammatory and hypoglycemic activities have been examined. In addition, $\mathrm{LD}_{50}$ levels are also included.

In this work, an $\mathrm{LD}_{50}$ dose of limonene, a major component of the essential oil of Foeniculum vulgare, was determined to be $2.77796 \mathrm{~mL} / \mathrm{kg}$.

The current study clearly demonstrated the anti-inflammatory effect of limonene in vivo, equal to that of etodolac at $0.15 \mathrm{~mL} / \mathrm{kg}$ and $0.60 \mathrm{~mL} / \mathrm{kg}$ doses, and to that of indomethacin at a $0.30 \mathrm{~mL} / \mathrm{kg}$ dose. The anti-inflammatory activity of an $\mathrm{LD}_{50}$ level of limonene is determined to be $0.142 \mathrm{~mL} / \mathrm{kg}$ for rats.

Souza et. al. demonstrated the anti-inflammatory activity of limonene in the mouse model of pleurisy induced by zymosan (500 microg/cavity) and lipopolysaccharide (LPS) (250 ng/cavity), and this study supports our results ${ }^{19}$. In this study limonene was also effective in inhibiting the production of nitric oxide as well as a significant inhibition of gamma-interferon and IL-4 production by limonene. Yoon et. al. showed that limonene suppresses the lipopolysaccharide (LPS)-induced production of nitric oxide (NO), prostaglandin E2 ( $\mathrm{PGE}_{2}$ ), and pro-inflammatory cytokines in RAW 264.7 macrophages; detection of D-limonene reduced the expression of TNF-alpha, IL-1 $\beta$ and IL-6 in a dosedependent manner ${ }^{20}$. Hirota et. al. showed that limonene may have a potential anti-inflammatory effect useful for the treatment of bronchial asthma by inhibiting cytokines, reactive oxygen species (ROS) production, and inactivating eosinophil migration ${ }^{21}$. Kummer et. al. showed that limonene isolated from Citrus latifolia Tanaka essential oil (CLEO) had potential anti-inflammatory effects, likely by inhibiting proinflammatory mediators present in inflammatory exudate and leukocyte chemotaxis ${ }^{22}$. In Rehman et. al. D-limonene also effectively decreased the doxorubicin induced overexpression of NF- $\kappa \mathrm{B}, \mathrm{COX}-2$, iNOS and nitric oxide ${ }^{23}$.

Determination of the activity of limonene to prevent the inflammation induced by carrageenan, may result from the aforementioned mechanisms. Further research is needed to reveal the mechanism of the anti-inflammatory activity.

Limonene did not show hypoglycemic activity in diabetic mice. It is found that the limonene group had significant levels of glucose in the blood of healthy mice during the $1^{\text {st }}, 2^{\text {nd }}, 4^{\text {th }}$ and $24^{\text {th }}$ hours compared to the Glibenclamide group, but the ISS group had significant levels during the $2^{\text {nd }}$ hour only. However, since these values were within normal limits related to the starved blood glucose level, these observed values are considered to have no clinical significance.

\section{CONCLUSION}

As a result, we can conclude that limonene can be totally or partially responsible 
for the anti-inflammatory activity that volatile fennel oil extract produces, but is not responsible for the hypoglycemic activity. We think that by working on the limonene molecule, we can obtain a new drug that is as potent as indomethacin that has fewer and weaker side effects.

\section{REFERENCES}

1. Akgül, A. Species Science \& Technology: (1st edn), Publication of Food Technology Association: Ankara-Turkey, 1993; pp 96-98.

2. Pamuk, H.A. Encyclopedia of Medicinal Herbs, Pamuk Publishing and Printing: IstanbulTurkey, 1998; pp 272-543.

3. Özbek, H. Investigation of The Level of The Lethal Dose $50\left(\mathrm{LD}_{50}\right)$ and The Hypoglycemic Effect in Healthy and Diabetic Mice of Foeniculum vulgare Mill. Fruit Essential Oil Extract. Van Med.J. 2002, 9(4), 98-103.

4. Özbek, H.; Öztürk, M.; Bayram, İ.; Uğraş, S.; Çitoğlu, G.S. Hypoglycemic and Hepatoprotective Effects of Foeniculum vulgare Miller Seed Fixed Oil Extract in Mice and Rats. E.J.M. $\mathbf{2 0 0 3}, 8(2), 35-40$.

5. Özbek, H.; Uğraş, S.; Dülger, H.; Bayram, İ.; Tuncer, İ.; Öztürk, G.; Öztürk, A. Hepatoprotective effect of Foeniculum vulgare essential oil. Fitoterapia 2003, 74(3), 317-319.

6. Özbek, H.; Uğraş, S.; Bayram, İ.; Uygan, İ.; Erdoğan, E.; Öztürk, A.; Huyut, Z. Hepatoprotective effect of Foeniculum vulgare essential oil: A carbon-tetrachloride induced liver fibrosis model in rats. Scand. J. Lab. Anim. Sci. 2004, 31(1), 9-17.

7. Özbek, H. The anti-inflammatory activity of the Foeniculum vulgare L. essential oil and investigation of its median lethal dose in rats and mice. Int. J. Pharmacol. 2005, 1(4), 329-331.

8. Simándi, B.; Deák, A.; Rónyani, E.; Yanxiang, G.; Veress, T.; Lemberkovics, E.; Then, M.; Sass-Kiss, A.; Vamos-Falusi, Z. Supercritical carbon dioxide extraction and fractionation of Fennel oil. J. Agric. Food. Chem. 1999, 47, 1635-1640.

9. Del Toro-Arreola, S.; Flores-Torales, E.; Torres-Lozano, C.; Del Toro-Arreola, A.; TostadoPelayo, K.; Guadalupe, Ramirez-Duenas, M.; Daneri-Navarro, A. Effect of D-limonene on immune response in BALB/c mice with lymphoma. Int. Immunopharmacol. 2005, 5(5), 829838.

10. Yano, H.; Tatsuta, M.; Iishi, H.; Baba, M.; Sakai, N.; Uedo, N. Attenuation by d-limonene of sodium chloride-enhanced gastric carcinogenesis induced by N-methyl-N'-nitro-N-nitrosoguanidine in Wistar rats. Int. J. Cancer 1999, 82(5), 665-668.

11. Litchfield, J.T.; Wilcoxon, F.W.J. A simplified method of evaluating dose-effect experiments. J Pharmacol Exp Ther. 1949, 96, 99-113.

12. Kouadio, F.; Kanko, C.; Juge, M. et al. Analgesic and antiinflammatory activities of an extract from Parkia biglobosa used in traditional medicine in the Ivory Coast. Phytother Res. 2000, 14, 635-637.

13. Winter, C.A.; Risley, E.A.; Nuss, G.W. Carrageenin-induced edema in hind paw of the rats as an assay for antiinflammatory drugs. Proc. Soc. Exp. Biol. Med. 1962, 111, 544-547.

14. Rimbau, V.; Cerdan, C.; Vila, R. Antiinflammatory activity of some extracts from plants used in the traditional medicine of North-African countries (II). Phytother. Res. 1999, 13, 128-132. 
15. Inoue, K.; Motonaga, A.; Nishimura, T. et al. Mechanism of anti-inflammatory action of etodolac. Arzneimittelforschung 1991, 41(3), 235-239.

16. Rodriguez, H.; Perez, R.M.; Muñoz, H.; Perez, C.; Miranda, R. Inducción de diabetes en raton por medio de aloxana. Acta Med. 1975, XI, 33-36.

17. Singh, S.N.; Vats, P.; Suri, S. et al. Effect of an antidiabetic extract of Catharanthus roseus on enzymic activities in streptozotocin induced diabetic rats. $J$ Ethnopharmacol. 2001, 76, 269-277.

18. Hayran, O.; Özbek, H. Research And Statistical Methods In Health Sciences. 2 th ed., Nobel Tip Kitabevleri, Istanbul-Turkey, 2017.

19. Souza, M.C.; Siani, A.C.; Ramos, M.F.; Menezes-de-Lima, O.J.; Henriques, M.G. Evaluation of anti-inflammatory activity of essential oils from two Asteraceae species. Pharmazie 2oo3, $58(8), 582-586$.

20. Yoon, W.J.; Lee, N.H.; Hyun, C.G. Limonene suppresses lipopolysaccharide-induced production of nitric oxide, prostaglandin E2, and pro-inflammatory cytokines in RAW 264.7 macrophages. J. Oleo Sci. 2010, 59(8), 415-421.

21. Hirota, R.; Roger, N.N.; Nakamura, H.; Song, H.S.; Sawamura, M.; Suqanuma, N. Antiinflammatory effects of limonene from yuzu (Citrus junos Tanaka) essential oil on eosinophils. J. Food Sci. 2010, 75(3), 87-92.

22. Kummer, R.; Fachini-Queiroz, F.C.; Estevão-Silva, C.F.; Grespan, R.; Silva, E.L.; BersaniAmado, C.A.; Cuman, R.K.N. Evaluation of Anti-Inflammatory Activity of Citrus latifolia Tanaka Essential Oil and Limonene in Experimental Mouse Models. Evid. Based Complement. Alternat. Med. 2013, 2013, 1-8.

23. Rehman, M.U.; Tahir, M.; Khan, A.Q.; Khan, R.; Oday-O-Hamiza; Lateef, A.; Hassan, S.K.; Rashid, S.; Ali, N.; Zeeshan, M.; Sultana, S. D-limonene suppresses doxorubicin-induced oxidative stress and inflammation via repression of COX-2, iNOS, and NFkB in kidneys of Wistar rats. Exp. Biol. Med. 2014, 239(4), 465-476. 